\title{
Halal Logistics PEST Analysis: The Malaysia Perspectives
}

\author{
Mohamed Syazwan Ab Talib ${ }^{1}$, Abu Bakar Abdul Hamid ${ }^{1,2}$, Mohd Hafiz Zulfakar ${ }^{3}$ \& Ananda S. Jeeva ${ }^{4}$ \\ ${ }^{1}$ Faculty of Management, Universiti Teknologi Malaysia, Johor, Malaysia \\ ${ }^{2}$ Malaysia Institute of Transport, Universiti Teknologi MARA, Selangor, Malaysia \\ ${ }^{3}$ School of Business Information Technology \& Logistics, RMIT University, Melbourne VIC, Australia \\ ${ }^{4}$ Curtin Business School, Curtin University, Bentley WA, Australia \\ Correspondence: Mohamed Syazwan Ab Talib, Faculty of Management, Universiti Teknologi Malaysia, UTM \\ Johor, 81300 UTM Johor, Malaysia. Tel: 60-3-2180-5044. E-mail: msyazwan79@live.utm.my
}

Received: March 13, 2014 Accepted: April 11, 2014 Online Published: June 24, 2014

doi:10.5539/ass.v10n14p119

URL: http://dx.doi.org/10.5539/ass.v10n14p119

\begin{abstract}
Halal logistics is a global business, and the objective of this study is to analyse the general environment of Halal logistics in Malaysia by using the PEST Analysis. This study is exploratory in nature and applies literature survey and the External Factors Evaluation (EFE) Matrix methodology. The results generated 20 factors that externally influencing the Malaysia Halal logistics scene. Plus, from the analysis, the opportunities and threats are also showcased. This study is the first attempt to analyse the external environment of Malaysia Halal logistics industry, and it is hoped that this study will be a platform or future reference for more academic and professional research in Halal industry.
\end{abstract}

Keywords: Halal, Halal logistics, Halal supply chain, PEST analysis, Malaysia

\section{Introduction}

According to the Islamic Law (Shariah), Halal refers to anything that is lawful and permissible while the opposite of Halal is Haram that means forbidden and punishable. Al Jallad (2008) summarise that Halal and Haram governs a Muslim's way of life that not only restricted to food, but encompasses activities such as speech, behaviour, dress code and social manner. Placing the term Halal in the global business context, it is not only limited to Halal food business. The Halal market, according to the Ministry of International Trade and Industry Malaysia (MITI), covers three markets namely food, non-food (pharmaceuticals, toiletries, medical products, medical devices, and cosmetics) and services (logistics, packaging, branding, marketing, media coverage and tourism). The extensive list of Halal related markets indicates that Halal is truly a global business. Lada et al. (2009) recorded that Halal is in the realm of business and trade, and is becoming a symbol of quality assurance and a lifestyle. This is supported by Gayatri and Chew (2013) that Halal is one of the measures of service quality, and because of that, both Muslims and non-Muslims accepted Halal-certified products and services as it showcases quality, hygienic, safety, sustainable and wholesome (Golnaz et al., 2010; Marzuki et al., 2012; Aziz \& Chok, 2013; Ambali \& Bakar, 2013).

Another point worth mentioning why Halal is a global business is because of the vast Muslim population. In the year 2012, the Muslim population was 1.8 billion and come 2030, it is forecasted to be 2.2 billion (Grim \& Karim, 2011). This presents a good and strong business opportunity as the Halal market is massive and continues to expand because of dominance in Muslim population growth (Adams, 2011), and the fact that Muslims must consume and use only Halal products and services. Besides that, the non-Muslims too contribute to the strong demand for Halal products and services. For instance, Malaysia Investment Development Authority (MIDA) reported that the European Halal market is valued at US\$76 billion and the demand comes from non-Muslim countries such as the United Kingdom, France and Germany.

Since it is evident that Halal is a global business, scholars too appreciate the contribution of Halal fields in academia through various researches and discoveries. Halal related studies are found to contribute to the existing knowledge or open a new frontier in academic research. For example, Halal researches appraised the knowledge of marketing (Ahmed, 2008; Talib \& Razak, 2013), branding (Wilson \& Liu, 2010/2011), consumer behaviour (Lada et al., 2009; Alam \& Sayuti, 2011), Halal food product (Bonne et al., 2007; Ireland \& Rajabzadeh, 2011), 
information technology (IT) (Anir et al., 2008; Nasir et al., 2011) and banking (Butt \& Aftab, 2013). Furthermore, Halal studies opens up new fields in academic such as study of Halal logistics (Tieman, 2011; Tieman et al., 2012; Tieman et al., 2013; Talib et al., 2013), Halal tourism (Wan Hassan \& Awang, 2009; Haq \& Wong, 2010) and Halal higher education (Ahmad et al., 2011).

Subsequently, since Malaysia is a model for Muslim countries (Rabasa, 2003), and there is an emerging trend for Halal logistics (Iberahim et al., 2012; Kamaruddin et al., 2012a), the aim of this study is to analyse the general environment (macro-environment) of Halal logistics in Malaysia. Accordingly, this study will analyse the Halal logistics macro-environment by observing the political, economic, socio-culture and technological factors and perform the PEST Analysis. This study, thus far, is the first and only attempt to analyse the Malaysia Halal logistics environment and unearth the potential opportunities and threats. Therefore, it is hoped that it will contribute to the Halal logistics industry and stakeholders, and setting a platform for future works, for both Muslim and non-Muslim countries.

\section{Halal Logistics}

Traditionally, logistics emerged from the term physical distribution (Ballou, 2007), and according to Chen and Paulraj (2007) and Christopher (2011), logistics is the process of planning, implementing and controlling the efficient flow and storage of goods (materials, parts and finished inventory), services and related information, from the origin to the point of consumption, by ensuring cost-efficient orders are met. In addition, Lambert et al. (1998) states that the objective of logistics management is to achieve customer satisfaction by ensuring that products or services are made available at the right time, in the right quantity, with the right description and in good condition. Therefore, logistics management involves a series of activities namely transportation, storage and warehousing, inventory management, material management, product scheduling, customer service and so forth. Hence, to achieve total Halal logistics, these elements must also be Halal, and because of integrity issues and the complex nature of logistics and supply chain, the need for Halal logistics is ever more important.

Presently, Muslims are more aware of their food consumption (Bonne et al., 2007; Bonne \& Verbeke, 2008), and the need for Halal-certified products and services does not only matter during point of purchase or consumption, but the whole supply chain, from upstream to downstream (Tieman, 2011). Ideally, Tieman (2013) defined Halal logistics as the process of managing the procurement, movement, storage and handling of materials, parts, livestock, semi-finished or finished inventory both food and non-food, and related information and documentation flows through the organization and the supply chain in compliance with the general principles of Shariah. From this definition, it indicates that the distribution of Halal products and services depends on Halal logistics functions. This can be explained by Smith (2007) that the growth of Halal industry depends on the success of Halal logistics, and it is the key in facilitating the manufacturing and distribution of Halal products and services.

According to Tieman et al. (2012) and Tieman (2013), transportation, warehousing and terminal operation are critical areas for Halal logistics. This can be justified by Jaafar et al., (2011) and Talib et al. (2013) that many logistics service providers (LSP) are investing in Halal dedicated facilities into their operation, such as warehousing and transportation fleet specialized for Halal products storage and distribution. Furthermore, to conform to strict Halal requirements and fulfil customers' demand, LSP have gone extra miles to ensure Halal logistics success. Value-added services such as samak (ritual cleansing) or steam cleaning for containers, temperature-controlled warehouses, dedicated transport carriers, Halal-only tools and equipment and complete segregation during distribution and storage are some notable examples (Jaafar et al., 2011; Kamaruddin et al., 2012a; Tieman et al., 2012; Tieman, 2013).

In Malaysia, the reception of Halal logistics is very welcomed, but there are certain quarters of LSP who feels that Halal logistics adds in more costs (Talib et al., 2013). On one hand, Halal logistics is gaining popularity and interest among LSP as Halal logistics promises a lucrative business (Smith, 2007; Omar \& Jaafar, 2011; Kamaruddin et al., 2012a), but on the other hand, there are few LSP that offer total Halal logistics services, citing government supports, collaboration issues, lack of knowledge, and the perception of additional costs as the barriers (Talib et al., 2013). Nevertheless, although Halal logistics publications are limited and more academic research is needed (Zulfakar et al., 2012; Tieman 2013), Halal logistics related scholarly works have emerged considerably. Halal logistics research covers Halal logistics and supply chain (Tieman, 2011; Tieman et al., 2012; Tieman et al., 2013), training in Halal logistics (Pahim et al., 2012a/2012b), Halal transportation (Tan et al., 2012a and 2012b), willingness to pay for Halal logistics (Kamaruddin et al., 2012a), Halal packaging (Talib \& Johan, 2012), and food supply chain (Halaseh \& Sundarakani, 2012; Manzouri et al., 2013). 


\section{PEST Analysis}

PEST analysis is an acronym of political, economic, socio-culture, and technological factors that directly or indirectly influence firms in any industry (macro-environment) (Ward \& Rivani, 2005; Mohamed et al., 2010). PEST is a strategic tool to excess the external environment that provide a 'satellite view' of an industry, and a key instrument for monitoring trends in the external environment (Ward \& Rivani, 2005; Pulaj \& Kume, 2013). In a simpler explanation, the PEST factors are uncontrollable factors that can either be an opportunity or a threat to firms and industries. Additionally, there is several extension or additional environmental factors from the traditional PEST, such as PESTEL (additional environmental and legal factors) and STEEPLE (socio-cultural, technological, economic, environment, political, legal and ethical factors) (Ward \& Rivani, 2005; Mohamed et al., 2010). According to Peng and Nunes (2007), the use of PEST analysis is for two purposes. The first purpose is to analyse the position or condition of a particular firm or industry, and the second purpose is to analyse the feasibility of general management solutions in a business environment. David (2011) described PEST analysis as a tool to identify and evaluate external opportunities and threats, enables organisations to develop clear mission, to design strategies, to achieve long-term objectives, and to develop policies to achieve annual objectives.

The use of PEST analysis as a tool for strategic planning is expressed by Lynch (2012) and Koumparoulis (2013). It is expressed by Koumparoulis that PEST analysis allows firms to understand market growth and decline, positioning business, and knowing the potential and direction for operations. Furthermore, many studies have performed PEST analysis in different fields such as in the automobile industry (Xiaomei et al., 2009), online payment services (Lao \& Jiang, 2009), e-government (Yingfa \& Hong, 2010), ecological study (Jianbo, 2012), construction industry (Pulaj \& Kume, 2013) and logistics industry (von der Gracht \& Darkow, 2010). However, there are several limitations to PEST analysis. Lynch (2012) commented that listing exhaustive factors will result into little significant and showcased lack of any serious consideration in the strategic management process. Burt et al. (2006) argued that the 'laundry list' are somehow generic and brings little contribution. Plus, Burt et al. stressed that the lack of interrelationships among the variables will cause difficulties in understanding how the factors influenced the environment. However, von der Gracht and Darkow (2010) discovered that the use of PEST analysis allows better forecast for any unforeseen scenario, and provide a valuable basis for strategy development. This, somehow, is consistent with Lynch (2012) assessments that although PEST analysis relies on past events and experiences, the analysis can be used as a forecast for the future.

\section{Methodology}

The methodology consists of two parts. The first part is an extensive review of Halal related literatures and previous studies. The literatures are retrieved from distinguished online library databases such as Scopus, Science Direct, Emerald, EBSCOHost, ProQuest and Directory of Open Access Journal (DOAJ). Literatures are gathered by using keywords such as Halal, Halal Logistics, Halal Supply Chain, PEST/PESTAL/STEP/STEEP Analysis and External Environmental Analysis. Since this study is exploratory in nature, literature survey technique is appropriate (Zikmund, 2003), and it helps to ensure that no important and frequently discussed variables that have an impact on the research area are ignored (Sekaran, 2003). A total of 119 English literatures were collected that comprises of journal articles, conference proceedings, books and trade magazines.

The second part of the methodology is the weighted score method that uses External Factor Evaluation (EFE) Matrix. An EFE Matrix consists a list of external factors to indicate and evaluate the relative importance of political, economic, socio-culture and technological factors in Malaysia Halal logistics (Mohamed et al., 2010; David, 2011). The list of external factors is extracted from the literature survey. Moreover, the use of EFE Matrix is a systematic method that will allow stakeholders and strategists to identify the available opportunities and avoid potential threats.

\section{Results}

\subsection{Political Factors}

The role of government in Halal logistics is significant (Samsi et al., 2011), and involve many tasks that include planning, developing, implementing, regulating, promoting and educating Halal to service providers and consumers. In Malaysia, the political factors comes from government intervention in the form of certification, procedures and policies, promotion, tax incentives and financial backing (Ramli, 2006; Muhammad et al., 2009; Tan et al., 2012a; Talib, 2014). Besides, government plays an important role in supporting and promoting logistics industry (Peng \& Vellenga, 1993). MITI, in the Third Industrial Master Plan (IMP3), aims to make Malaysia a Halal hub for the production and trade in Halal goods and services. To achieve this, one of the measures is tax incentives, which includes tax exemption, tax drawbacks and double deduction for logistics and shipping sub-sectors and Halal LSP. Besides, special grants are given to LSP to become Halal-compliant, and 
any LPS will enjoy double tax deduction on expenditure for obtaining Halal certification and accreditation (MITI, 2006). The initiative from the government is supported by Tan et al. (2012a) that government support and incentives is an encouragement for new investment in Halal logistics, as well as in increasing the use of information communication technology (ICT) in Halal logistics. Furthermore, Tan et al. (2012a) perceived the Standards for Halal Logistics (MS2400:2010) is a good strategy to stamp Malaysia's commitment in supporting Halal logistics growth. This is consistent with a study by Talib (2014), which highlighted government support also comes in the form of policies, procedures and guidelines. The following are examples of Malaysia Standards for Halal Logistics:

1) MS1500:2004 Malaysia Standards for General Guidelines on the Production Preparation, Handling and Storage of Halal Food.

2) MS2400-1:2010 Halalan-Toyyiban Assurance Pipeline - Part 1: Management System Requirements for Transportation of Goods and/or Cargo Chain Services.

3) MS2400-2:2010 Halalan-Toyyiban Assurance Pipeline - Part 2: Management System Requirements for Warehousing and Related Activities

Moreover, the Malaysia government, through its agency, the Department of Islamic Development Malaysia (JAKIM), is known for its Halal certification (Muhammad et al., 2009) and Malaysia's Halal certification in an exemplary among Organization of the Islamic Conference (OIC) countries and is claimed to be a model system by the United Nation. Not only that, Malaysia Halal standards is recognized by the Codex Alimentarius Commission, and it is also the only reference and guidelines on Halal products recognized by the World Trade Organization (WTO) (Adams, 2011). Furthermore, government or political factors can be seen through the rapid development and capital supports for building Halal dedicated infrastructures. The IMP3 reported developing Halal Park and Halal Distripark to cater for Halal product and services, including Halal Logistics (MITI, 2006). Government interventions and efforts in developing key logistics infrastructures such as seaports will speed industry's growth (Goh \& Pinaikul, 1998), and in the case of Malaysia, three international seaports have expressed interest in becoming a Halal-compliant seaport (MITI, 2006).

Although Malaysia's Halal certification is recognized worldwide, it still comes with numerous challenges and can be a threat to the development of Halal industry, including Halal logistics. Among the Halal certification issues encountered, according to Shafie and Othman (2006) are:

1) lack of consistency in the definition of Halal on the aspect of animal slaughtering,

2) the release of Halal logo by individual firms,

3) use of Arabic-sounded or Islamic-signalled brand names,

4) the rampant use of Quran verses or Arabic characters, and

5) lack of authority enforcement in resolving abused Halal logos.

Depicting the first and second issues mentioned above, the lack of standardisation in Halal certification causes great confusion and problems among consumers and Halal LSP (Iberahim et al., 2012). Besides that, although there are 122 Halal certifying bodies all around the world (International Halal Integrity Alliance, 2011), JAKIM only recognised 71 foreign Halal certification bodies and authorities from 29 countries (Talib, 2014). In addition, studies have shown that applying new or renewing Halal certification are inefficient, tedious, time consuming and costly (Abdul et al., 2009; Noordin et al., 2009). Hence, this resulted into more product manufacturers and service providers prone to opt of an easier but illegal way, by acquiring fake Halal certification.

\subsection{Economic Factors}

In the year 2013, Frost \& Sullivan forecasted the Malaysia logistics industry at US\$45.1 billion, and with constant government support, Malaysia's strategic location and good external trade, Malaysia logistics industry is in a strong and healthy position. Meanwhile, MITI estimates the global Halal market value for trade in Halal food and non-food products is estimated at US\$2.1 trillion annually. These figures are good indication that Halal logistics is at the forefront to benefit from the vast and lucrative Halal market. According to Talib (2014), logistics is an enabler for Halal import and export as various modes and types of transport and intermodal are required. Therefore, Talib (2014) adds that Halal logistics should take the opportunity from the ASEAN Free Trade Area (AFTA), by distributing Halal products among AFTA members. The ASEAN market is very promising as between the year 2009 and 2011, the Intra-ASEAN trade among the participating countries recorded growth and was valued at US\$598 billion and, Malaysia holds one of the biggest total trade values of US\$108 billion. (MITI, 2008). 
One of the indicators for economic factor, according to Mohamed et al. (2010) is consumer confidence. Confidence among Halal consumers is strong, judging from the vast Muslim population and acceptance among non-Muslim consumers. For instance, the European and American Halal market are valued at US\$76 billion and US\$12.35 billion respectively (MITI, 2006). These numbers are very encouraging because of the large Muslim population in Europe (51.2 million people) and in America (6 million people). Still, these numbers will continue to grow because of worldwide migration (Adams, 2011).

Furthermore, PricewaterhouseCoopers $(\mathrm{PwC})$ reported that the Halal market is the largest in the world and are largely overlooked and untapped. Apart from Halal food, there are series of new categories been created to showcase that Halal concept and application is moving beyond food and thus creating a Halal value chain. On top of the Halal market categorised by MITI, there are various new Halal categories in the market such as Halal professional services, Halal entertainment, Halal communication channel, and Halal apparel. The existing and new Halal categories will require the need of Halal logistics to extend the distribution and further ensure the Halal status remain intact, as mentioned by Tieman (2011) and Tieman (2013), Halal logistics extends and protects the Halal status and integrity until the final consumers.

\subsection{Socio-culture Factors}

As mentioned earlier, Muslims consumers are more aware, knowledgeable and concern on their food intakes (Bonne et al., 2007; Bonne \& Verbeke, 2008). In the case of Malaysia consumers, they are concerned on the Halal status of a product or service, whether the Halal logo is genuine or not (Shafie \& Othman, 2006; Abdul et al., 2009). Apart from being more concern and knowledgeable, Abdul et al. discovers that trust and confidence are the driver towards purchasing Halal products. Furthermore, aside from conforming to Islamic teaching, the reason to choose Halal products and services are because of health reasons (Ambali \& Bakar, 2013). Halal products are known to be prepared in a hygienic and clean environment Aziz and Chok (2013), and this resulted into healthy and safe for consumption or usage (Bonne \& Verbeke, 2008). Additionally, some consumers also deemed Halal product and services are kind to the animal welfare. For instance, there are abattoirs in Spain practices Halal slaughtering in order to cater for demanding consumers who are concern about animal welfare and pre-slaughter logistics chain (Miranda-de la Lama et al., 2010).

The change in consumer preferences has caused products and service providers to respond. For example, study done by Kamaruddin et al. (2012a) discover that Halal logistics is a lucrative business as more consumers are willing to pay for Halal logistics and some event willing to pay premium (Tieman et al., 2013). The change in consumer preference towards Halal-compliant logistics resulted into modification and new addition from conventional logistics services. For instance, many LSP are investing in Halal-dedicated assets such as Halal warehousing, Halal seaport, Halal transportation and carrier, Halal-only equipment, Halal-audit teams, Halal tracking, and steam/samak services (Jaafar et al., 2011; Kamaruddin et al., 2012b; Talib et al., 2013). Although there are many initiatives from the LSP, limited talent and knowledge of Halal logistics is a hindering factor (Talib et al., 2013). The reason behind this is due to the fact that there is scarce of experts about Halal logistics. Knowledge of both Halal and logistics must be hand-in-hand in order to achieve incomparable Halal logistics services, but as mentioned earlier, there is lack of professionals in logistics industry.

Looking at the demographic factors, population growth, age, education levels, level of religiosity, and geographical area play a significant role in Halal logistics, and Halal industry as a whole. As expressed at the beginning part, the Muslim population growth and dominance in Halal market contributes to the massive acceptance (MITI, 2006; Adams, 2011). However, the level of understanding and acceptance of Halal logistics is affected because of age, education levels, level of religiosity, and geographical area (Rezai et al., 2009). According to Rezai et al., there is significant different between younger and older respondents. In Malaysia, the older generations are more concern on Halal labelled products. However, this is different from Tieman et al. (2013) findings as the younger generations have a higher degree on preference (concern) for Halal product. In terms of geographical location, Rezai et al. (2009) discover that Muslims from the East Coast of Malaysia are more concerned on Halal compared to the West Coast. Plus, Tieman et al. (2013) discovered that there are differences in consumers' perception on Halal logistics between Muslim and non-Muslim countries. Tieman et al. (2013) concludes that there are different Halal logistics standards for Muslim and non-Muslim countries.

\subsection{Technological Factors}

Firms must be alert to changes in technology as it will alter the ways firm operate their businesses (Mohamed et al., 2010). According to Mazlan (2005) and Tieman (2010), the use of information technology is gaining interest in Halal logistics and LSP should take this as an opportunity. Besides that, the use of IT in Halal logistics is a profitable business (Zailani et al., 2010), and the application of IT will enhances Halal product or service 
integrity along the supply chain (Bahrudin et al., 2011; Tan et al., 2012a) as it allows tracking and tracing services. In addition, Talib (2014) agreed that due to the complexity of logistics activities, the use of IT in logistics allows better Halal integrity, and enhance performance efficiency. Meanwhile, Tieman (2010) expressed that IT in Halal logistics offers greater transparency and control. To enjoy the full benefit of IT in Halal logistics, Tan et al. (2012a) recommend government support is vital in order to reduce adoption barrier and promote IT in Halal logistics.

According to Tan et al. (2012a), IT is applied in Halal logistics, such as Transportation Management System (TMS), Warehouse Management System (WMS), Electronic Data Interchange (EDI) and Global Positioning System (GPS). Not only that, Radio Frequency Identification (RFID) is also used in Halal logistics (Bahrudin et al., 2011; Nasir et al., 2011). According to Bahrudin et al. the use of RFID is on the rise, but many companies are resistant to change as they preferred the traditional real-time tracking method of using the short message services (SMS) (Anir et al., 2008). Tan et al. (2012a) too discovered that, although it is not a major factor, organizations afraid their employees might not be familiar with the system as it is a complex learning process. Other issues are the compatibility issue as different customers or companies uses different systems, and it causes inconsistency. Although the use of RFID is at an infant stage here in Malaysia, it is gaining acceptance among consumers, and it can help strengthen Malaysia status as the world Halal hub (Norman, 2009).

Furthermore, apart from using sophisticated IT, more innovative and simple methods of detecting Halal certified products and services have been introduced to the consumers. Consumers are now able to cross-check the authenticity of a Halal logo by using their phone (Mohd Albakir \& Mohd Mokhtar, 2011). This free Halal logo detection and recognition system is linked with JAKIM's database and eases the mind of Halal consumers. Junaini and Abdullah (2008) further enhance technology adoption on Halal products by using a camera phone barcode scanning and multimedia message service (MMS) to check a product's Halal status. These technology services can also be used for Halal logistics services as it will allow manufacturers, retailers or consumers to know which logistics service providers that are certified Halal. Table 1 summarises the political, economic, socio-cultural, and technological literature survey of Halal logistics in Malaysia.

Table 1. Halal logistics PEST analysis review summary

\begin{tabular}{|c|c|}
\hline Factors & Source \\
\hline $\begin{array}{l}\text { Political Factors } \\
\text { - The government gives tax incentives } \\
\text { - The use of Malaysia Standards in Halal logistics } \\
\text { - Worldwide recognition of Malaysia Halal certification } \\
\text { - The government has established Halal logistics infrastructure } \\
\text { - No uniformity in international Halal certification } \\
\text { - Use of dubious Halal certification }\end{array}$ & $\begin{array}{l}\text { MITI (2006); Ramli (2006); Shafie \& Othman } \\
\text { (2006); Abdul et al. (2009); Muhammad et al. } \\
\text { (2009); Noordin et al. (2009); Adams (2011); } \\
\text { Samsi et al. (2011); Iberahim et al. (2012); Tan et } \\
\text { al. (2012a); Talib (2014) }\end{array}$ \\
\hline $\begin{array}{l}\text { Economic Factors } \\
\text { - Strong logistics economy growth } \\
\text { - Strong and promising Malaysia external trade } \\
\text { - Vast Halal market potential among AFTA countries } \\
\text { - Other emerging Halal markets }\end{array}$ & $\begin{array}{l}\text { MITI (2006); MITI (2008); Mohamed et al. } \\
\text { (2010); Adams (2011); Tieman (2011); Tieman } \\
\text { (2013); Talib (2014) }\end{array}$ \\
\hline $\begin{array}{l}\text { Socio-cultural Factors } \\
\text { - Consumers are more aware, educated and concern about Halal } \\
\text { - Change in consumers' preferences towards Halal } \\
\text { - Dominance of Muslim population in Malaysia and overseas } \\
\text { - Greater demand for Halal food products and services } \\
\text { - Knowledge and talent Scarcity } \\
\text { - Different demographic factors among Muslim consumers }\end{array}$ & $\begin{array}{l}\text { MITI (2006); Shafie \& Othman (2006); Bonne et } \\
\text { al. (2007); Bonne \& Verbeke, (2008); Abdul et al. } \\
\text { (2009); Rezai et al. (2009); Miranda-de la Lama } \\
\text { et al. (2010); Adams (2011); Kamaruddin et al. } \\
\text { (2012a); Kamaruddin et al. (2012b); Ambali \& } \\
\text { Bakar (2013); Aziz \& Chok (2013); Talib et al. } \\
\text { (2013); Tieman et al. (2013) }\end{array}$ \\
\hline $\begin{array}{l}\text { Technological Factors } \\
\text { - Increase use of IT in Halal logistics } \\
\text { - Innovation in Halal logistics services } \\
\text { - Service providers are resistant to change } \\
\text { - System compatibility along the Halal logistics supply chain }\end{array}$ & $\begin{array}{l}\text { Mazlan (2005); Anir et al. (2008); Junaini \& } \\
\text { Abdullah (2008); Norman (2009); Mohamed et al. } \\
\text { (2010); Tieman (2010); Zailani et al. (2010); } \\
\text { Bahrudin et al. (2011); Mohd Albakir \& Mohd } \\
\text { Mokhtar (2011); Nasir et al. (2011); Tan et al. } \\
\text { (2012a) }\end{array}$ \\
\hline
\end{tabular}




\subsection{Halal Logistics External Analysis}

This section is dedicated to analysing the external environment, looking at the political, economic, socio-cultural and technological factors, by assigning weights to each of the factors. Table 2 shows the External Factor Evaluation (EFE) Matrix of Halal logistics in Malaysia. From the literature survey performed earlier, there are 20 factors that externally influencing the Malaysia Halal logistics industry. The list is adequate as suggested by Mohamed et al. (2010) and David (2011), a total of 15 to 20 items is sufficient. There are 6, 4, 6 and 4 sub-factors for political, economic, socio-cultural and technological factors respectively. All factors are assigned with relationship importance rating from 1 to 10 to indicate the relative importance in the Halal logistics industry. The score of 10 indicates that the factor is extremely important while the score of 1 indicates that the factor is extremely unimportant. 2 factors are rated extremely important ("worldwide recognition of Malaysia Halal certification" and "increase use of IT in Halal logistics"), and the lowest rating is 5 with only 3 factors. The weights for all factors are obtained from subtracting the individual value with the total relationship importance rating of 140. Accordingly, a score of 1 to 5 is given to all factors to determine firms' response towards the factors, where 5 (the response is superior), 4 (the response is good), 3 (the response is average), 2 (the response is poor) and 1 (there is no response). The weighted score is obtained from individually multiplying the weight and score of all factors. It must be highlighted that the average total weighted score is 3.0. A total weighted score of 5.0 indicates that the industry is responding well while the total score of 1.00 indicates that the industry is underachieving. The Halal logistics total weighted score is 3.31, is above average, thus indicating the industry is performing above average.

Table 2. Halal logistics EFE matrix

\begin{tabular}{|c|c|c|c|c|}
\hline Factors & $\begin{array}{l}\text { Relationship } \\
\text { Importance } \\
\text { Rating } \\
(1-10)\end{array}$ & Weight & $\begin{array}{l}\text { Score } \\
(1-5)\end{array}$ & $\begin{array}{l}\text { Weighted } \\
\text { Score }\end{array}$ \\
\hline \multicolumn{5}{|l|}{ Political Factors } \\
\hline - The government gives tax incentives & 8 & 0.06 & 5 & 0.30 \\
\hline - The use of Malaysia Standards in Halal logistics & 7 & 0.05 & 4 & 0.20 \\
\hline - Worldwide recognition of Malaysia Halal certification & 10 & 0.07 & 3 & 0.21 \\
\hline - The government has established Halal logistics infrastructure & 6 & 0.04 & 2 & 0.08 \\
\hline - No uniformity in international Halal certification & 6 & 0.04 & 3 & 0.12 \\
\hline - Use of dubious Halal certification & 5 & 0.04 & 4 & 0.16 \\
\hline \multicolumn{5}{|l|}{ Economic Factors } \\
\hline - Strong logistics economy growth & 8 & 0.06 & 4 & 0.24 \\
\hline - Strong and promising Malaysia external trade & 6 & 0.04 & 4 & 0.16 \\
\hline - Vast Halal market potential among AFTA countries & 5 & 0.04 & 2 & 0.08 \\
\hline - Other emerging Halal markets & 6 & 0.04 & 3 & 0.12 \\
\hline \multicolumn{5}{|l|}{ Socio-cultural Factors } \\
\hline - Consumers are more aware, educated and concern about Halal & 7 & 0.05 & 3 & 0.15 \\
\hline - Change in consumers' preferences towards Halal & 7 & 0.05 & 4 & 0.20 \\
\hline - Dominance of Muslim population in Malaysia and overseas & 6 & 0.04 & 3 & 0.12 \\
\hline - Greater demand for Halal food products and services & 8 & 0.06 & 3 & 0.18 \\
\hline - Knowledge and talent scarcity & 8 & 0.06 & 2 & 0.12 \\
\hline - Different demographic factors among Muslim consumers & 5 & 0.04 & 1 & 0.04 \\
\hline \multicolumn{5}{|l|}{ Technological Factors } \\
\hline - Increase use of IT in Halal logistics & 10 & 0.07 & 5 & 0.35 \\
\hline - Innovation in Halal logistics services & 7 & 0.05 & 3 & 0.15 \\
\hline - Service providers are resistant to change & 8 & 0.06 & 3 & 0.18 \\
\hline - System compatibility along the Halal logistics supply chain & 7 & 0.05 & 3 & 0.15 \\
\hline Total & 140 & 1.00 & & 3.31 \\
\hline
\end{tabular}


From the Table 2 above, the political factors influenced the Halal logistics industry the most with a combined total average score of 1.07 , followed by technological factors $(0.83)$, socio-cultural factors $(0.81)$ and economic factors $(0.60)$. The economic factors recorded the least total weighted score and this support the study by Adams (2011) that demand for Halal products and services will continue to grow and will not experience decrease in import or export because of rising Muslims' personal income and population growth. The sub-factor "increased use of IT in Halal logistics" scores the highest weighted score with 0.35 . Due to the complex nature of Halal logistics supply chain (Tieman, 2013), and growing awareness among consumers (Bonne et al., 2007; Bonne \& Verbeke, 2008), the use of IT Halal logistics is ever more important and becoming a lucrative market (Zailani et al., 2010). Therefore, the finding is accepted and consistent with previous studies. Moreover, the lowest total weighted score is 0.04 , the "different demographic factors among Muslim consumers" from the socio-cultural factors. The score reflect that it does not matter what age, gender, education level or geographic location, all Muslims should abide by the Shariah way of life. The weighted scores of all sub-factors are obtained and sorted to generate the potential opportunities and threats of the external environment. Table 3 depicts the Halal logistics opportunities and threats.

Table 3. Halal logistics opportunities and threats

\begin{tabular}{ll}
\hline Opportunities & Weighted Score \\
\hline - Increase use of IT in Halal logistics & 0.35 \\
- The government gives tax incentives & 0.30 \\
- Strong logistics economy growth & 0.24 \\
- Worldwide recognition of Malaysia Halal certification & 0.21 \\
- The use of Malaysia Standards in Halal logistics & 0.20 \\
- Change in consumers' preferences towards Halal & 0.20 \\
Threats & Weighted Score \\
- Service providers are resistant to change & 0.18 \\
- Use of dubious Halal certification & 0.16 \\
- System compatibility along the Halal logistics supply chain & 0.15 \\
- No uniformity in international Halal certification & 0.12 \\
- Knowledge and talent scarcity & 0.12 \\
- Different demographic factors among Muslim consumers & 0.12 \\
\hline
\end{tabular}

Focusing on the treats, the result indicates the service providers are resistant to change, and this is in line with findings from Bahrudin et al. (2011) and Talib et al. (2013). The reason behind this maybe because of the perception that Halal logistics is difficult to attain and adds more costs. The use of doubtful Halal certification is also a threat, and this causes consumer dissatisfaction and again, supports the findings from Farouk et al. (2006) that there are traces of non-Halal substances on Halal food packaging, a function in Halal logistics. The limited talent and know-how in Halal logistics is also a threat (Talib et al., 2013), and this must be addressed by both the government and LSP. Failure to address this threat will create other problems such as fraudulent of certification or corrupted Halal authorities.

\section{Conclusion}

The aim of this study is to analyse the general environment (macro-environment) of Halal logistics in Malaysia, and results shows there are 20 factors externally influencing the industry. In addition, Mohamed et al. (2010) states the external factor analysis matrix provides a more systematic method to assist strategists in capitalising the opportunities and avoiding or minimizing the threats. Since political factors are the most influential towards Halal logistics industry, the government should exploit by encouraging small-medium logistics enterprises to adopt Halal approach in their operation. However, the use of doubtful Halal certification must be eradicated in order to preserve Malaysia's Halal certification as the best in the world. Furthermore, the government should encourage more international liaison among AFTA countries in order to sprung Halal logistics to a greater height. By looking at neighbouring countries, Malaysia can expand its Halal logistics network and distribution. In addition, stronger initiative should be undertaken by both government and LSP in terms of IT usage, as it is the second most influential factor. A more worldwide approach is recommended as not only the IT component will generate a new source of revenue, but it will also provide more convenient and a piece of mind for Muslims worldwide. Additionally, since the socio-cultural factors indicate that consumers are more aware of Halal, but 
there is lack of talent and experts in Halal logistics, more efforts should be emphasised in educating the public of what Halal logistics is and how it is important for a wholesome Halal product or service. The higher education sector should take this advantage by offering programs or courses dedicated towards supplying more Halal logistics experts and spreading the knowledge of Halal entirely.

Several limitation of this study need to be highlighted. Firstly, PEST analysis is not a complete reflection of the industry as the external environment is forever changing, plus it is only a 'snapshot' of the factors in the environment at a moment in time (Burt, 2006), and the PEST factors are purely a reminder list that should be used selectively (Lynch, 2012). Secondly, this study is qualitative in nature and lack empirical evident. Hence, future study should focus on quantifying all external factors, in order to produce a more solid PEST analysis. Besides, future research on Halal logistics PEST analysis should perform a cross-country study in order to unearth environmental differences between a Muslim and non-Muslim country. Accordingly, to further understands the external environment, Burt (2006) recommends scenario planning methodology to help improve the process of analysing and understanding the environment, and helping in adapting to changes in the external environment. Finally, this study is the first attempt to analyse the Halal logistics environment in Malaysia, and it is hoped that this study will be a platform or future references for more academic and professional research in Halal industry, specifically the Halal logistics.

\section{References}

Abdul, M., Ismail, H., Hashim, H., \& Johari, J. (2009). SMEs and halal certification. China-USA Business Review, 8(4), 22-29.

Adams, I. A. (2011). Globalization: Explaining the dynamics and challenges of the halāl food surge. Intellectual Discourse, 19(1), 123-145.

Ahmed, A. (2008). Marketing of halal meat in the United Kingdom: Supermarkets versus local shops. British Food Journal, 110(7), 655-670. http://dx.doi.org/10.1108/00070700810887149

Al Jallad, N. (2008). The concepts of al-halal and al-haram in the Arab-Muslim culture: A translational and lexicographical study. Language Design: Journal of Theoretical and Experimental Linguistics, 10, 77-86.

Alam, S. S., \& Sayuti, N. M. (2011). Applying the Theory of Planned Behavior (TPB) in Halal food purchasing. International Journal of Commerce and Management, 21(1), 8-20. http://dx.doi.org/10.1108/1056921 1111111676

Ambali, A. R., \& Bakar, A. N. (2013). Ḥalāl food and products in Malaysia: People's awareness and policy implications. Intellectual Discourse, 21(1), 7-32.

Anir, N. A., Nizam, M. N. M. H., \& Masliyana, A. (2008). The users' perceptions and opportunities in Malaysia in introducing RFID system for Halal food tracking. WSEAS Transactions on Information Science and Applications, 5(5), 843-852.

Aziz, Y. A., \& Chok, N. V. (2013). The Role of Halal Awareness, Halal Certification, and Marketing Components in Determining Halal Purchase Intention among Non-Muslims in Malaysia: A Structural Equation Modeling Approach. Journal of International Food \& Agribusiness Marketing, 25(1), 1-23. http://dx.doi.org/10.1080/ 08974438.2013.723997

Bahrudin, S. S. M., Illyas, M. I., \& Desa, M. I. (2011). Tracking and tracing technology for halal product integrity over the supply chain. In 2011 International Conference on Electrical Engineering and Informatics (ICEEI) (pp. 1-7). IEEE. http://dx.doi.org/10.1109/ICEEI.2011.6021678

Ballou, R. H. (2007). The evolution and future of logistics and supply chain management. European Business Review, 19(4), 332-348. http://dx.doi.org/10.1108/09555340710760152

Bonne, K., \& Verbeke, W. (2008). Muslim consumer trust in halal meat status and control in Belgium. Meat Science, 79(1), 113-123. http://dx.doi.org/10.1016/j.meatsci.2007.08.007

Bonne, K., Vermeir, I., Bergeaud-Blackler, F., \& Verbeke, W. (2007). Determinants of Halal meat consumption in France. British Food Journal, 109(5), 367-386. http://dx.doi.org/10.1108/0070700710746786

Burt, G., Wright, G., Bradfield, R., Cairns, G., \& van der Heijden, K. (2006). The role of scenario planning in exploring the environment in view of the limitations of PEST and its derivatives. International Studies of Management and Organization, 36(3), 50-76. http://dx.doi.org/10.2753/IMO0020-8825360303

Butt, M. M., \& Aftab, M. (2013). Incorporating attitude towards Halal banking in an integrated service quality, satisfaction, trust and loyalty model in online Islamic banking context. International Journal of Bank 
Marketing, 31(1), 6-23. http://dx.doi.org/10.1108/02652321311292029

Chen, I. J., \& Paulraj, A. (2004). Understanding supply chain management: Critical research and a theoretical framework. International Journal of Production Research, 42(1), 131-163. http://dx.doi.org/10.1080/0020 7540310001602865

Christopher, M. (2011). Logistics \& Supply Chain Management. Dorchester, UK: Financial Times/Prentice Hall.

David, F. R. (2011). Strategic Management: Concepts and Cases. Singapore: Pearson

Farouk, A. E., Batcha, M. F., Greiner, R., Salleh, H. M., Salleh, M. R., \& Sirajuddin, A. R. (2006). The use of a molecular technique for the detection of porcine ingredients in the Malaysian food market. Saudi Medical Journal, 27(9), 1397-1400.

Gayatri, G., \& Chew, J. (2013). How do Muslim consumers perceive service quality? Asia Pacific Journal of Marketing and Logistics, 25(3), 472-490. http://dx.doi.org/10.1108/APJML-06-2012-0061

Goh, M., \& Pinaikul, P. (1998). Logistics management practices and development in Thailand. Logistics Information Management, 11(6), 359-369. http://dx.doi.org/10.1108/09576059810242471

Golnaz, R., Zainalabidin, M., Mad Nasir, S., \& Eddie Chiew, F. C. (2010). Non-Muslims' awareness of Halal principles and related food products in Malaysia. International Food Research Journal, 17, 667-674.

Grim, B. J., \& Karim, M. S. (2011). The Future of the Global Muslim Population: Projections for 2010-2030. Washington DC: Pew Research Center.

Halaseh, L. A., \& Sundarakani, B. (2012). Study on quality attributes of halal food supply chain. International Journal of Logistics Economics and Globalisation, 4(1), 20-34. http://dx.doi.org/10.1504/IJLEG.2012. 047212

Haq, F., \& Wong, H. Y. (2010). Is spiritual tourism a new strategy for marketing Islam? Journal of Islamic Marketing, 1(2), 136-148. http://dx.doi.org/10.1108/17590831011055879

Hasan, A., Fazullah, A., Abidin, A. Z., \& Abdul Jalil, B. (2011). Halal Studies in Universities: A Way Forward to Manage Halal Business. In International Journal of Arts and Sciences Conference (IJAS2011) Austria (pp. $1-9)$.

Iberahim, H., Kamaruddin, R., \& Shabudin, A. (2012). Halal development system: The institutional framework, issues and challenges for halal logistics. In 2012 IEEE Symposium on Business, Engineering and Industrial Applications (ISBEIA) (pp. 760-765). IEEE. http://dx.doi.org/10.1109/ISBEIA.2012.6422993

International Halal Integrity Alliance. (2011). Halal in a Box. Retrieved from http://www.ihialliance.org/hiab.php

Ireland, J., \& Rajabzadeh, S. A. (2011). UAE consumer concerns about Halal products. Journal of Islamic Marketing, 2(3), 274-283. http://dx.doi.org/10.1108/17590831111164796

Jaafar, H. S., Endut, I. R., Faisol, N., \& Omar, E. N. (2011). Innovation in logistics services-halal logistics. In the $16^{\text {th }}$ International Symposium on Logistics (ISL) (pp. 844-851).

Jianbo, L. (2012). Study on Practice of and Measures for Ecological Compensation Mechanism in the Three Georges Reservoir Area from SWOT-PEST Analysis. In 2012 Fourth International Conference on Computational and Information Sciences (ICCIS) (pp. 1353-1356). IEEE.

Junaini, S. N., \& Abdullah, J. (2008). MyMobiHalal 2.0: Malaysian mobile halal product verification using camera phone barcode scanning and MMS. In International Conference on Computer and Communication Engineering, 2008. ICCCE 2008 (pp. 528-532). IEEE.

Kamaruddin, R., Iberahim, H., \& Shabudin, A. (2012a). Willingness to Pay for Halal Logistics: The Lifestyle Choice. Procedia-Social and Behavioral Sciences, 50, 722-729. http://dx.doi.org/10.1016/j.sbspro.2012. 08.075

Kamaruddin, R., Iberahim, H., \& Shabudin, A. (2012b). Halal compliance critical control point (HCCCP) analysis of processed food. In 2012 IEEE Business Engineering and Industrial Applications Colloquium (BEIAC) (pp. 383-387). IEEE.

Koumparoulis, D. N. (2013). PEST Analysis: The case of E-shop. International Journal of Economy, Management and Social Sciences, 2(2), 31-36.

Lada, S., Tanakinjal, G. H., \& Amin, H. (2009). Predicting intention to choose halal products using theory of reasoned action. International Journal of Islamic and Middle Eastern Finance and Management, 2(1), 
66-76. http://dx.doi.org/10.1108/17538390910946276

Lambert, D. M., Stock, J. R., \& Ellram, L. M. (1998). Fundamentals of Logistics Management. Boston, NY: Irwin/McGraw-Hill.

Lao, G., \& Jiang, S. (2009). Risk Analysis of Third-Party Online Payment Based on PEST Model. In International Conference on Management and Service Science, 2009 (MASS'09) (pp. 1-5). IEEE. http://dx.doi.org/10.1109/ICMSS.2009.5302516

Lynch, R. (2012). Strategic Management. Singapore: Pearson.

Manzouri, M., Rahman, M. N. A., Saibani, N., \& Mohd Zain, C. R. C. H. (2013). Lean Supply Chain Practices in the Halal Food. International Journal of Lean Six Sigma, 4(4), 4. http://dx.doi.org/10.1108/IJLSS-102012-0011

Marzuki, S. Z. S., Hall, C. M., \& Ballantine, P. W. (2012). Restaurant Manager and Halal Certification in Malaysia. Journal of Foodservice Business Research, 15(2), 195-214. http://dx.doi.org/10.1080/15378020. 2012.677654

Mazlan, M. (2005). Innovation diffusion and ICT adoption in JAKIM Halal certified company in Klang Valley. (Unpublished Doctoral dissertation). Universiti Teknologi MARA (UiTM), Selangor, Malaysia.

Ministry of International Trade and Industry (MITI). (2006). Malaysia Third Industrial Master Plan (IMP3) 2006-2020. Kuala Lumpur: Pencetakan Nasional Malaysia Berhad.

Ministry of International Trade and Industry Malaysia (MITI). (2008). Intra-ASEAN Trade, 2009-2011. Retrieved from http://www.miti.gov.my/cms/storage/documents/20b/com.tms.cms.document.Document 4ed83b41-c0a8157334cb34cb1172038b/1/IntraASEAN20TRADE2C20200920112028Preliminary20figures 2920-20Vallue20in20US2420milliion.pdf

Miranda-de la Lama, G. C., Villarroel, M., Liste, G., Escós, J., \& María, G. A. (2010). Critical points in the pre-slaughter logistic chain of lambs in Spain that may compromise the animal's welfare. Small Ruminant Research, 90(1), 174-178. http://dx.doi.org/10.1016/j.smallrumres.2010.02.011

Mohamed, Z. A., Ann, H. J., \& Yee W. F. (2010). Strategic Management. Selangor: Oxford Fajar.

Mohd Albakir, S. N. W. S., \& Mohd-Mokhtar, R. (2011). A conceptual design of genuine Halal logo detector. In 2011 IEEE International Conference on Imaging Systems and Techniques (IST) (pp. 296-301). IEEE. http://dx.doi.org/10.1109/IST.2011.5962198

Muhammad, N. M. N., Isa, F. M., \& Kifli, B. C. (2009). Positioning Malaysia as Halal-Hub: Integration role of supply chain strategy and halal assurance system. Asian Social Science, 5(7), 44-52.

Nasir, M., Norman, A., Fauzi, S., \& Azmi, M. (2011). An RFID-based validation system for Halal food. International Arab Journal of Information Technology, 8(2), 204-211.

Noordin, N., Noor, N. L. M., Hashim, M., \& Samicho, Z. (2009). Value chain of halal certification system: A case of the Malaysia halal industry. In European and Mediterranean Conference on Information Systems (EMCIS2009). Retrieved from http://www.researchgate.net/publication/200114389_Value_Chain_of_Halal _Certification_System_A_Cas_of_the_Malaysian_Halal_Industry/file/79e4150bec082e7181.pdf

Norman, A. A., Nasir, M. H. N. M., Fauzi, S. S. M., \& Azmi, M. (2009). Consumer acceptance of RFID-enabled services in validating halal status. In $9^{\text {th }}$ International Symposium on Communications and Information Technology, (ISCIT 2009) (pp. 911-915). IEEE. http://dx.doi.org/10.1109/ISCIT.2009.5340977

Omar, E. N., \& Jaafar, H. S. (2011). Halal supply chain in the food industry-A conceptual model. In 2011 IEEE Symposium on Business, Engineering and Industrial Applications (ISBEIA) (pp. 384-389). IEEE. http://dx.doi.org/10.1109/ISBEIA.2011.6088842

Pahim, K. M. B., Jemali, S., \& Mohamad, S. J. A. N. S. (2012a). An empirical research on relationship between demand, people and awareness towards training needs: A case study in Malaysia Halal logistics industry. In 2012 IEEE Business Engineering and Industrial Applications Colloquium (BEIAC) (pp. 246-251). IEEE.

Pahim, K. M. B., Jemali, S., \& Mohamad, S. J. A. N. S. (2012b). The importance of training for Halal logistics industry in Malaysia. In 2012 IEEE Symposium on Humanities, Science and Engineering Research (SHUSER) (pp. 1635-1640). IEEE. http://dx.doi.org/10.1109/SHUSER.2012.6268847

Peng, G. C., \& Nunes, M. B. (2007). Using PEST analysis as a tool for refining and focusing contexts for information systems research. Proceedings of the 6th European Conference on Research Methodology for 
Business and Management Studies (pp. 229-237). Academic Conferences Limited.

Peng, L., \& Vellenga, D. (1993). The government's role in promoting logistics services in China. Logistics and Transportation Review, 29(4), 301-318.

Pulaj, E., \& Kume, V. (2013). How The Albanian External Environment Affect the Construction Industry. Annales Universitatis Apulensis-Series Oeconomica, 15(1), 295-309.

Rabasa, A. (2003). Political Islam in Southeast Asia: Moderates, Radicals and Terrorists. Oxford: Oxford University Press for the International Institute for Strategic Studies.

Ramli, N. (2006). Halal-the new global market force. Retrieved from http://www.skrine.com/halal-the-new -global-market-force-part-1

Samsi, S. Z. M., Tasnim, R., \& Ibrahim, O. (2011). Stakeholders' role for an efficient traceability system in halal industry supply chain. In Annual International Conference on Enterprise Resource Planning and Supply Chain Management (ERP-SCM 2011). Retrieved from http://www.academia.edu/attachments/3273429/ download_file

Sekaran, U. (2003). Research Methods for Business: A Skill Building Approach. New Jersey, NY: Wiley.

Shafie, S., \& Othman, M. N. (2006). Halal Certification: An international marketing issues and challenges. In International IFSAM VIIIth World Congress. Retrieved from http://halalrc.org/images/ResearchMaterial/ Report/HalalCertificationaninternationalmarketingissuesandchallenges.pdf

Smith, C. C. (2007). Halal Logistics a Fast-growing Market. Bangkok Post. Retrieved from http://halalrc.org/images/ResearchMaterial/Literature/Halallogisticsafastgrowingmarket.pdf

Talib, A. N. A., \& Razak, I. S. A. (2013). Cultivating export market oriented behavior in halal marketing: Addressing the issues and challenges in going global. Journal of Islamic Marketing, 4(2), 187-197. http://dx.doi.org/10.1108/17590831311329304

Talib, M. S. A. (2014). Halal Logistics in Malaysia: A SWOT Analysis. Journal of Islamic Marketing, 5(3). In-press.

Talib, M. S. A., \& Johan, M. R. M. (2012). Issues in halal packaging: A conceptual paper. International Business and Management, 5(2), 94-98.

Talib, M. S. A., Rubin, L., \& Zhengyi, V. K. (2013). Qualitative Research on Critical Issues in Halal Logistics. Journal of Emerging Economies and Islamic Research, 1(2), 1-20.

Tan, M. I. I., Razali, R. N. \& Husny, Z. J. (2012b). The Adoption of Halal Transportations Technologies for Halal Logistics Service Providers in Malaysia. In Proceedings of World Academy of Science, Engineering and Technology. World Academy of Science, Engineering and Technology.

Tan, M. I. I., Razali, R. N., \& Desa, M. I. (2012a). Factors influencing ICT adoption in halal transportations: A case study of Malaysian halal logistics service providers. International Journal of Computer Science Issues, $9(1), 62-71$.

Tieman, M. (2010). Halal Logistics. Retrieved from http://www.logasiamag.com/article/halallogistics/1744

Tieman, M. (2011). The application of Halal in supply chain management: In-depth interviews. Journal of Islamic Marketing, 2(2), 186-195. http://dx.doi.org/10.1108/17590831111139893

Tieman, M. (2013). Establishing the principles in halal logistics. Journal of Emerging Economies and Islamic Research, 1(1), 1-13.

Tieman, M., Ghazali, M. C., \& van der Vorst, J. G. (2013). Consumer perception on halal meat logistics. British Food Journal, 115(8), 1112-1129. http://dx.doi.org/10.1108/BFJ-10/2011-0265

Tieman, M., van der Vorst, J. G., \& Ghazali, M. C. (2012). Principles in halal supply chain management. Journal of Islamic Marketing, 3(3), 217-243. http://dx.doi.org/10.1108/17590831211259727

von der Gracht, H. A., \& Darkow, I. L. (2010). Scenarios for the logistics services industry: A Delphi-based analysis for 2025. International Journal of Production Economics, 127(1), 46-59. http://dx.doi.org/10.1016/ j.ijpe.2010.04.013

Wan Hassan, W. M., \& Awang, K. W. (2009). Halal food in New Zealand restaurants: An exploratory study. International Journal of Economics and Management, 3(2), 385-402.

Ward, D., \& Rivani, E. (2005). An Overview of Strategy Development Models and the Ward-Rivani Model. 
Economics Working Papers.

Wilson, J. A., \& Liu, J. (2010). Shaping the Halal into a brand? Journal of Islamic Marketing, 1(2), 107-123. http://dx.doi.org/10.1108/17590831011055851

Wilson, J. A., \& Liu, J. (2011). The challenges of Islamic branding: Navigating emotions and Halal. Journal of Islamic Marketing, 2(1), 28-42. http://dx.doi.org/10.1108/17590831111115222

Xiaomei, L., Zhaofang, M., \& Ershi, Q. (2009). Study on Global Logistics Integrative System and Ke Technologies of Chinese Automobile Industry. In International Conference on Management and Service Science, 2009 (MASS'09) (pp. 1-4). IEEE.

Yingf, S., \& Hong, Y. (2010). The Risk Study of E-Governance Based on PEST Analysis Model. In 2010 International Conference on E-Business and E-Government (ICEE) (pp. 563-566). IEEE. http://dx.doi.org/10.1109/ICEE.2010.150

Zailani, S., Arrifin, Z., Abd Wahid, N., Othman, R., \& Fernando, Y. (2010). Halal Traceability and Halal Tracking Systems in Strengthening Halal Food Supply Chains for Food Industry in Malaysia (A Review). Journal of food Technology, 8(3), 74-81. http://dx.doi.org/10.3923/jftech.2010.74.81

Zikmund, W. G. (2012). Business Research Methods. Ohio, USA: South-Western.

Zulfakar, M., Jie, F., \& Chan, C. (2012). Halal food supply chain integrity: From a literature review to a conceptual framework. In 10th ANZAM Operations, Supply Chain and Services Management (pp. 1-23). Australia and New Zealand Academy of Management.

\section{Copyrights}

Copyright for this article is retained by the author(s), with first publication rights granted to the journal.

This is an open-access article distributed under the terms and conditions of the Creative Commons Attribution license (http://creativecommons.org/licenses/by/3.0/). 